\title{
11. Carnivora from the Baynunah Formation
}

\section{Camille Grohé}

Division of Paleontology, American Museum of Natural History, New York, NY, U.S.A.; Laboratory Paleontology Evolution Paleoecosystems Paleoprimatology (PALEVOPRIM, UMR CNRS 7262), University of Poitiers, France camille.grohe@univ-poitiers.fr

\begin{abstract}
I describe new specimens of carnivoran mammals from the continental late Miocene Baynunah Formation, exposed in the western coastal region of Abu Dhabi Emirate. New material collected between 2002 and 2014 includes dental specimens of the mustelid Plesiogulo sp. and a large-sized hyaenid, postcranial remains and an upper canine of a largesized machairodontine felid, postcrania and a tooth of a medium-sized felid, and postcrania of a medium-sized mustelid. The latter two are new taxonomic records for the Baynunah Formation. With a minimum of six species, the carnivoran assemblage from the Baynunah Formation is the richest known from the Miocene of the Arabian Peninsula.
\end{abstract}

Running head: Carnivora 


\section{Introduction}

Fossil carnivorans from the Miocene of the Arabian Peninsula and nearby regions (Figure 11.1A) are scarce compared to contemporaneous Eurasian and African records. From the early Miocene, a humerus of an indeterminate viverrine was described from the Hatzeva Formation of the Rotem Basin in the Negev (Tchernov et al. 1987). Tchernov et al. (1987) also described a mandible of the creodont cf. Anasinopa haasi from the same basin. One indeterminate carnivoran occurs in the Dam Formation at Ghaba (ca. 17.5-15.5 Ma), Sultanate of Oman (Thomas et al. 1999). Remains of the viverrid Viverra sp., the mustelids cf. Martes sp. and Mionictis sp., the felid Pseudaelurus turnauensis, and the amphicyonid Amphicyon sp. were described (but not figured) from the Dam Formation at Al-Sarrar (= As-Sarrar) (ca. 17-15 Ma), Saudi Arabia (Thomas et al. 1982). The Al-Sarrar carnivore community is similar to contemporaneous faunas from western Europe. A maxillary fragment (P2-P4 and alveolus of M1) and an isolated p4 of the large hyaenid-like carnivore Percrocuta sp. were reported from the middle Miocene Hofuf Formation at Al-Jadidah (ca. 12-13 Ma), Saudi Arabia (Thomas et al. 1978; figured in Howell and Petter 1985, pl. 2, fig. 2). This material is similar in size to fossils of $P$. tobieni from the middle Miocene Ngorora Formation of Kenya (Crusafont-Pairó and Aguirre 1971). One indeterminate carnivoran might also occur in the middle Miocene Dam Formation at Ad-Dabtiyah, northwest of Al-Jadidah (phalanx listed by Hamilton et al. 1978). The fossil record from the late Miocene includes the felid Machairodus sp. from the Bekaa Valley of Lebanon, near Kefraya (Kansou 1961; Malez and Crnolatac 1961), as well as ?Machairodus sp. and an indeterminate possible mustelid from the Lower Bakhtiari Formation, Jebel Hamrin (ca. 10-9 Ma) in Iraq (Thomas et al. 1980). Finally, the Baynunah Formation, located in Abu Dhabi Emirate, has yielded the only late Miocene terrestrial fauna from the Arabian Peninsula (Whybrow \& Hill 1999; Bibi et al. this volume-a). Barry (1999) previously described dental and postcranial specimens belonging to the mustelid Plesiogulo 
praecocidens, a large machairodontine felid, and one large and one medium-sized hyaenid. In this chapter, I describe new material of Carnivora collected between 2002 and 2014.

\section{PLACE FIGURE 11.1 ABOUT HERE; WIDTH = 2 COLUMNS}

\section{Material and methods}

Over the past four decades, numerous fossiliferous sites have been documented along the western coast of Abu Dhabi Emirate, where the Baynunah Formation is exposed over an area about $200 \mathrm{~km}$ long and $30 \mathrm{~km}$ wide (Bibi et al. this volume-b). Ten sites have yielded remains of Carnivora (Figure 11.1.B). Outcrops of the Baynunah Formation reach a maximum thickness of $60 \mathrm{~m}$ and are composed of conglomerates and sandstones deposited in a fluvial paleoenvironment (Ditchfield 1999; Schuster this volume). Biochronology coupled with magnetostratigraphy suggest an age between 8 and 6 Ma for the Baynunah Formation, possibly between 7.7 and 7.0 Ma (Hailwood and Whybrow 1999; Whybrow and Clements 1999; Peppe et al., this volume). Its fauna is comparable with those of late Miocene sites in Africa, such as Sahabi in Libya, Toros-Menalla in Chad, and Lothagam and the Tugen Hills in Kenya (Bibi et al. 2013; Bibi et al. this volume-c). Detailed information on all Baynunah fossil localities is given by Bibi et al. (this volume-b).

The machairodontine upper canine fragment was photographed using a Zeiss EVO 60 Scanning Electron Microscope at the Microscopy and Imaging Facility of the American Museum of Natural History (MIF AMNH). Dental and postcranial measurements were taken with digital calipers to the nearest $0.1 \mathrm{~mm}$. When access to the material was not possible, measurements were taken from photos and these are indicated.

Institutional abbreviations: AMNH, American Museum of Natural History, New York; F:AM, Frick Mammal collection, AMNH; FM, Fossil Mammal collection, AMNH; IMNH, 
Idaho Museum of Natural History, Pocatello, ID; KNM, National Museums of Kenya; -LT, Lothagam; -PQ-L, fossils from Langebaanweg; SAM, Iziko South African Museum. The material described in this chapter is housed with the Abu Dhabi Department of Culture and Tourism (formerly Tourism and Culture Authority, formerly Abu Dhabi Authority for Culture and Heritage), U.A.E., and their accession numbers bear the prefix AUH.

\section{Systematic Paleontology}

Order CARNIVORA Bowdich, 1821

Suborder CANIFORMIA Kretzoi, 1943

Superfamily ARCTOIDEA Flower, 1869

Family MUSTELIDAE Fischer, 1817

Genus PLESIOGULO Zdansky, 1924

PLESIOGULO sp.

(Fig. 11.2, Table 11.1)

Previously published material. AUH 45, left mandible with canine and p2-m1 from Hamra, HMR 5 (figured by Barry 1999, fig. 17.1-17.2, p. 204, described as Plesiogulo praecocidens); AUH 702, right mandible fragment with p3 and broken p4 from Hamra, HMR 6 (figured by Barry 1999, fig. 17.3, p. 205, described as Plesiogulo praecocidens).

New material. AUH 1762, left M1 fragment lacking mesiobuccal edge, from Ruwais Southeast, RUW SE. 
Description. The left M1 (Fig. 11.2K, Table 11.1) is broken mesiobuccally so that the buccal shelf of the paracone and the preprotocrista are partly missing. The paracone is higher and wider than the metacone. The paracone is twice as long as the metacone mesiodistally. The paracone and metacone are separated by a distinct notch. The buccal shelf of the paracone is much wider than the metacone buccal shelf. The protocone is small and crestiform. The preprotocrista, extending distolingually from the mesial border of the tooth, is marked by a small notch. The postprotocrista is very short and projects distobuccally as far as approximately half the mesiodistal length of the lingual rim of the molar. A faint crest extends from the paracone tip to the middle of the preprotocrista. The lingual portion of the M1 bulges distally so that the lingual rim is longer mesiodistally than the buccal rim. The lingual border is concave at the middle of its length. A cingulum surrounds the tooth; it is especially thick lingually.

Comparisons. Plesiogulo is a widespread hypercarnivore known from late Miocene to early Pliocene localities in Eurasia, Africa and North America. Barry (1999) described left (AUH 45) and right (AUH 702) mandibular fragments of Plesiogulo praecocidens (Kurtén, 1970) from the Baynunah Formation. This attribution was based on "their relatively small size" and the "absence of the carnassial metaconid" (Barry 1999, p. 204, table 17.1). The robustness of the teeth, the absence of accessory cusps on the premolars, and the elongated $\mathrm{m} 1$ in which the talonid breadth is similar to that of the trigonid indicate that this material belongs to Plesiogulo. However, on the mandible AUH 45, the distolingual region of $\mathrm{m} 1$ is worn and it is not possible to determine with certainty the presence or absence of a metaconid. Moreover, the holotype of P. praecocidens, from the late Miocene locality 49 of Baode (China), shows in fact an $\mathrm{m} 1$ metaconid, small and very distal relative to the protoconid tip (L. Werdelin, pers. comm.). Regarding the size, the small dimensions of the Baynunah Plesiogulo distinguish it 
from the large-sized North American P. lindsayi Hendey, 1981 and P. marshalli (Martin, 1928), the Chinese P. major Teilhard, 1945 and the European and South African $P$. monspessulanus Viret, 1939 (e.g., Hendey 1978; Harrison 1981; Table 11.1). The Baynunah form falls into the size variation of the small to medium-sized Asian P. praecocidens Kurtén, 1970, P. brachygnathus (type species of Plesiogulo, originally described as "Lutra" brachygnathus by Schlosser 1903), P. minor Teilhard, 1945 and Eurasian P. crassus Teilhard, 1945 (e.g., Schlosser 1903; Kurtén 1970; Koufos 1982). Much taxonomic confusion exists for P. major and for the small to medium-sized species of Plesiogulo (e.g., Zdansky 1924; Teilhard de Chardin 1945; Kurtén 1970; Harrison 1981).

The upper molar AUH 1762 exhibits distolingual expansion and metacone reduction as in Plesiogulo. The specimen corresponds in size and hypercarnivore morphology to the same species as the mandibles AUH 45 and AUH 702. According to Kurtén (1970), P. praecocidens has a very lingually expanded M1, with an "inner lobe markedly rounded in outline". In fact, in $P$. praecocidens, the distal expansion of M1 occurs closely behind the metacone, while it is more lingual in the Baynunah specimen. Moreover, AUH 1762 differs from the M1 of $P$. praecocidens by having a narrower buccal shelf and by being shorter, although it has a very similar width (M1 width/lingual length ratio is 1.11 in $P$. praecocidens, based on M1 measurements from Kurtén 1970, and 1.2 for AUH 1762). Compared with other Plesiogulo species, the Baynunah M1 is much smaller than in the eastern African P. botori Haile-Selassie et al., 2004 and the previously discussed $P$. marshalli, $P$. lindsayi, $P$. major and $P$. monspessulanus (e.g., Haile-Selassie et al. 2004; Table 11.1).

Because of the morphological differences exhibited between the Baynunah form and $P$. praecocidens and the need for revision of the small to medium-sized species of Plesiogulo (e.g., Koufos 1982 and Haile-Selassie et al. 2004 for a taxonomic summary), I decide to attribute the Baynunah form to Plesiogulo sp. 
PLACE FIGURE 11.2 ABOUT HERE; WIDTH = 1,5 COLUMN

PLACE TABLE 11.1 ABOUT HERE

\section{MUSTELIDAE INDET.}

(Fig. 11.2, Table 11.2)

\section{Previously published material. None.}

Material. AUH 1046, right distal femur from Kihal, KIH 2-1. AUH 1055, left broken ulna from Hamra, HMR 1-1. AUH 1752, proximal and distal parts of right humerus from Kihal, KIH 2-1.

Description. The partial right humerus AUH 1752 (Fig. 11.2A-D) preserves a complete humeral head and lesser tuberosity and a distally broken greater tuberosity. The humeral head is rather high proximodistally and its neck curves gently in the posterodistal direction. The proximal part of the greater tuberosity does not extend more proximally than the head, unlike the condition in cursorial mammals. The lesser tuberosity is convex and displays a semicircular shape in medial view, the proximal margin of the tuberosity being straight. A longer fragment with the distal epiphysis and the partial diaphysis belongs to the same individual. The medial epicondyle is twice as wide lateromedially as the lateral one and it does not extend to the distal margin of the trochlea. The lateral supinator crest is more extended posteriorly than laterally and merges with the diaphysis above the level of the entepicondylar foramen in posterior view. The entepicondylar foramen is wider in anterior view than in posterior view, where it stretches proximodistally. There is no supratrochlear foramen in 
anterior view, and the radial fossa is wider and higher than the coronoid fossa. A deep olecranon fossa is present above the trochlea in posterior view.

The left ulna AUH 1055 (Fig. 11.2E-G) is broken at its distal end and proximal to the anconeal process, so that it lacks the olecranon. The proximal and distal margins of the trochlear notch are of similar width and show a similar anterior extension in lateral and medial views. The radial notch is triangular in shape and slightly concave. The proximal ulna curves gently in the anterior direction, unlike in cursorial mammals. A deep longitudinal groove for the $M$. brachialis (flexor of the elbow) is visible in anterior view on the mediodistal corner of the trochlear notch. On the lateral side of the bone, the insertion area for the M. abductor pollicis longus (abductor of the thumb at the carpometacarpal joint and partial abductor of the wrist), is relatively flat. In medial view, a slight convex area for the $M$. pronator quadratus (forearm pronator) is visible distally.

The right distal femur fragment AUH 1046 (Fig. 11.2H-J) preserves a lateral condyle, that is narrower than the medial condyle. The medial condyle also extends slightly more distally than the lateral condyle. The patellar trochlea seems poorly grooved, although it is broken laterally and medially. The epicondyles as well as the anterior region proximal to the condyles are rugose and bear small pits.

Comparisons. This material shows important morphological differences with postcranial remains of Plesiogulo described and/or figured in the literature (e.g., P. monspessulanus, $P$. marshalli and P. lindsayi in Hendey 1978 and Harrison 1981). AUH 1752 differs from the humeri of Plesiogulo marshalli (AMNH F:AM 67650A, AMNH F:AM 108052, Harrison, 1981, fig. 11a-c, f-g, p. 16, and personal observations) and P. monspessulanus (SAM-PQL40042, Hendey 1978, fig. 5A, p. 338) in having a less rectangular shape of the entepicondylar foramen, a more laterally extended supinator crest and being smaller (Table 
11.2; Hendey 1978, table 3, p. 339; Harrison 1981, table 4, p.13). It further differs from the humeri of $P$. marshalli in having a semicircular lesser trochanter instead of an elongated one. AUH 1752 recalls the morphology observed in other mustelids: the degree of development of the medial epicondyle and the supinator crest is similar to that observed in Amblonyx cinerea (AMNH 101639), and the supinator crest is as prominent as in Mustela vison (AMNH 128510), Martes pennanti (AMNH 181992), Meles meles (AMNH 70604), and Mellivora capensis (AMNH 89011), which indicate similar patterns of extension in the elbow, wrist and digits. This humerus is close in size to that of the fisher Martes pennanti, whose body weight is between 1.3 and $5.5 \mathrm{~kg}$ (Nowak, 1991).

The ulna AUH 1055 exhibits a semilunar notch that is as wide distally as proximally, which is different from the condition seen in similar-sized felids and hyaenids, where it is much wider distally. It differs from the ulnae of $P$. marshalli (AMNH F:AM 108052, Harrison, 1981, fig. 11d-e, p. 16, and personal observations) and P. lindsayi (AMNH F:AM 67957, Harrison 1981, fig. 16e-f, p. 24, and personal observations) in its larger radial notch, wider proximal margin of the semilunar notch, presence of a deep groove for $m$. brachialis, and shorter length (Table 11.2; Harrison 1981, table 4, p. 13, table 6, p. 20). It also differs from the ulna of P. monspessulanus by its larger radial notch and shorter length (SAM-PQL40042, Hendey 1978, fig. 6, p. 340, table 3, p. 339). In the mustelids examined (Amblonyx cinerea, Mustela vison, Martes pennanti, Meles meles, Mellivora capensis), the radial notch is more elongated anteroposteriorly and mediolaterally than in the Abu Dhabi specimen. A deep groove for the M. brachialis is present in Martes, Mustela, and Amblonyx, as in AUH 1055. The femur and ulna from the Baynunah fauna were recovered from the same locality and could correspond to the same species given their size (Table 11.2). Dental material would be needed in order to identify the taxon to which these postcranial remains belong. 


\author{
Suborder FELIFORMIA Kretzoi, 1945 \\ Family FELIDAE Fischer, 1817 \\ Subfamily MACHAIRODONTINAE Gill, 1872 \\ HOMOTHERINI INDET. (Fabrini, 1890)
}

(Fig. 11.3, Table 11.3)

Previously published material. AUH 202, last lumbar vertebra from Ras Dubay'ah, RDB 2 (figured here, Fig. 11.3O-R, Table 11.3). AUH 241, complete right calcaneum from Kihal, KIH 1 (figured by Barry 1999, fig. 17.4, p. 207, refigured here, Fig. 11.3E-H, Table 11.3).

New material. AUH 852, distal epiphysis of metapodial from Shuwaihat, SHU 9. AUH 1056, distal epiphysis of right humerus from Hamra, HMR 1-1. AUH 1576, lumbar vertebra from Thumayriya, THM 1. AUH 1678, caudal vertebra from Hadwaniyya, HAD 5. AUH 1756, fragment of upper canine from Hamra, HMR 5.

Description. The upper canine AUH 1756 (Fig. 11.3A) is laterally compressed and long, considering that the proximal crown is missing (Table 11.3). Its tip is worn and the enamel is mostly flaked off. One fragment of enamel associated with this tooth shows coarse carinal crenulations (Fig. 11.3B). Whether this enamel fragment belongs to the anterior or posterior edges of the upper canine is not determinable.

The distal right humerus AUH 1056 is greatly eroded (Fig. 11.3C-D, Table 11.3) but preserves a medial entepicondylar foramen extending along the longitudinal axis of the bone. The medial epicondyle, although broken and blunt in its distal part, is moderately developed. 
There is no supratrochlear foramen but a deep olecranon fossa is visible in posterior view above the trochlea.

The metapodial AUH 852 preserves only the distal epiphysis (Fig. 11.3I-J, Table 11.3), which makes the attribution to a metacarpal or metatarsal impossible to assess.

The lumbar vertebra AUH 1576 (Fig. 11.3K-N, Table 11.3) has a broken dorsal neural spine and ventral transverse processes, as well as partially broken postzygapophyses (its dorsal branches) and right accessory process. The vertebral centrum appears narrower and less high posteriorly than anteriorly. The anterior accessory processes are present, rather thin, and extend up to the level of half the prezygapophyses. The postzygapophyseal surfaces are slightly concave. The height of the laterodorsal projections of the postzygapophyses cannot be evaluated due to breakage. The transverse processes, broken at their dorsal bases, lie on the lateroventral sides of the vertebral centrum, extending ventrally from the anterior third of the centrum. Several morphological features indicate an intermediate position of the vertebra in the lumbar series. When compared to Panthera leo (AMNH FM 2437), AUH 1576 is unlikely to correspond to L4-L7, as accessory processes are barely developed in L4-L5 and are absent in L6-L7. When compared to other homotherins, AUH 1576 is similar to L3 and L4 of Homotherium ischyrus (IMNH 900-11862; Hearst et al. 2011, fig. 6.12, p.144 and fig. 6.13, p. 148 ) in the degree of development of its accessory processes, and it is similar to L3 and L4 of Machairodus catocopis (AMNH F:AM 104044, personal observation), in the degree of development of its accessory processes, prezygapophyses, and transverse processes.

The caudal vertebra is rather circular in transversal section (Fig. 11.3S, Table 11.3). The posterior part is lacking. A small transverse process arises along the right anterior border of the vertebra, indicating a rather posterior position of the specimen in the caudal series of the Baynunah species. 
Comparisons and discussion. The felid elements described here could represent several individuals of the same species as they fall within an intraspecific range of size variation. The large, coarse crenulations present on the upper canine recall the morphology seen in late Miocene to Pleistocene Homotherini, in contrast to Smilodontini, which show minute serrations or a lack of serrations in the case of Promegantereon and Megantereon (Salesa et al 2010; Christiansen and Adolfssen 2007). The third tribe of Machairodontinae, the Metailurini, are found mostly in older localities (early to middle Miocene), except Metailurus and Dinofelis, which are known from the late Miocene to early Pleistocene (Werdelin et al. 2010). Metailurins have less derived sabre-tooth adaptations (e.g., lack of crenulations or serrations on the upper canines for Metailurus and Dinofelis [see Werdelin and Lewis 2001 for Dinofelis]) and they are smaller in size than the Baynunah form.

Large-sized Homotherini of the late Miocene include Lokotunjailurus, Machairodus, and Amphimachairodus. Lokotunjailurus is known from two species, L. emageritus and $L$. fanonei, from the late Miocene of Kenya and Chad, respectively (Werdelin 2003; Bonis et al. 2010a). The genus is characterized by "serrations ... on both anterior and posterior edges" (Werdelin 2003, p. 294) of the upper canine (the term serration here does not refer to the width of the carinal ornamentations). The postcranial elements available for L. emageritus, include humeri and calcanei, the morphology of which is similar to the Baynunah specimens but dimensions are smaller (humerus KNM-LT 26178 figured in Werdelin 2003, fig. 7.25 A-B, p. 299; calcanei KNM-LT 23940 and KNM-LT 23037 figured in Werdelin 2003, fig. 7.29 K-N, p. 303, measurements Werdelin 2003, table 7.18, p. 324 and tables 7.20, 7.22, p. 327; see Table 11.2).

Taxonomic attributions to Machairodus and Amphimachairodus are sometimes debated (see Werdelin et al. 2010). Antón et al. (2004) proposed restricting the genus Machairodus to Vallesian forms (11.2-9 Ma), while Turolian forms (9-5.3 Ma) could represent a more derived 
stage in machairodont adaptations with Amphimachairodus. Given that the Baynunah Formation is dated to 8-6 Ma, this hypothesis would favor the attribution of the present felid to Amphimachairodus rather than Machairodus, although the age argument alone cannot be used to rule out other homotherin genera. Machairodus has been reported, but not described, from the late Miocene of Jebel Hamrin, Iraq (Thomas et al. 1980) and the Bekaa Valley of Lebanon, near Kefraya (Kansou 1961; Malez and Crnolatac 1961). There is a possibility that the same species occurs in Abu Dhabi during the late Miocene.

PLACE FIGURE 11.3 ABOUT HERE; WIDTH = 2 COLUMNS

PLACE TABLE 11.3 ABOUT HERE

\section{Medium-sized FELIDAE INDET.}

(Fig. 11.4, Table 11.4)

\section{Previously published material. None.}

New Material. AUH 858, partial left m1 (partial trigonid) from Shuwaihat, SHU 9-1; AUH 1202, right metacarpal V from Shuwaihat, SHU 4-2; AUH 1292, left metacarpal V from Hamra, HMR 2-2; AUH 1217, proximal epiphysis of metapodial from Hamra, HMR 1-2.

Description. The m1 AUH 858 (Fig. 11.4A-B) partially preserves the distal crest of the paraconid and the anterior crest of the protoconid. A marked carnassial notch is present between these two crests. A basal cingulid is present on the buccal side. The lingual face is broken under the carnassial notch. AUH 858 lacks a metaconid directly lingual to the protoconid, but the presence or absence of a more distally placed metaconid is not certain. The 
fragment has a preserved anteroposterior length of $11.3 \mathrm{~mm}$ and the height from the basal cingulid to the carnassial notch is $8.8 \mathrm{~mm}$ (both measurements estimated from photos).

The right metacarpal V, AUH 1202 (Fig. 11.4C-G), has a strongly convex and dorsoventrally extended proximal facet for the unciform. This facet is separated from the lateral tuberosity for the $M$. extensor carpi ulnaris by a faint groove. The proximal and medial facet for metacarpal IV is markedly curved and flat dorsoventrally. A strong process extends proximodistally at the distodorsal border of the facet for the metacarpal IV. The distal end of metacarpal V is asymmetric, with a medial condyle deflected distomedially. The left metacarpal V, AUH 1292 (Fig. 11.4H-J), is larger than the right one, AUH 1202 (Table 11.4). The proximal metapodial, AUH 1217, is greatly eroded, but is similar in size to AUH 1292. All these specimens were collected from different localities and belong to different individuals.

Comparisons and discussion. The lack of a metaconid placed directly lingual to the protoconid coupled with its narrow shape suggest that AUH 858 belongs to a felid. The metacarpals V have similar proportions to the ones of Crocuta crocuta (AMNH 187769), but the morphology of the proximal epiphysis, notably the presence of a marked process on its medial face, is different from that in hyaenids and recalls felids. AUH 1292 is slightly larger than AUH 1202 and these metacarpals V are comparable in morphology to that of Metailurus parvulus, which may be similar in size to a clouded leopard (Roussiakis et al. 2006, fig. 7, p. 573), i.e. between 16 and $23 \mathrm{~kg}$ (Nowak 1991). However, the Baynunah metacarpals are much longer than that of Metailurus, which indicates a larger felid.

PLACE FIGURE 11.4 ABOUT HERE; WIDTH = 1,5 COLUMN

PLACE TABLE 11.4 ABOUT HERE 
HYAENIDAE Gray, 1829

Large-sized HYAENIDAE INDET.

(Fig. 11.5, Table 11.5)

Previously published material. AUH 294, left mandible with unerupted canine, intact dp2 and fragment of dp3 from Jebel Dhanna, JDH 3.

New material. AUH 1788, right lower canine from Shuwaihat, SHU 12-1; AUH 1548, buccal fragment of right P4 from Gerain al-Aysh, GAA 1.

Description. The right lower canine AUH 1788 shows very heavy wear on the mesiolabial side of the crown, resulting from occlusion with the upper canine (Fig. 11.5B-C). This heavy wear is characteristic of bone-cracking hyaenas. Wear is also visible on the lingual side and most probably corresponds to occlusion with the third upper incisor (Fig. 11.5A). Finally, wear is present on the distal wall of the canine and could have been produced by food itself, rather than occlusal wear (Fig. 11.5B). Undulating Hunter-Schreger bands are visible on the anterior and labial aspects of the tooth.

In the partial right P4, AUH 1548 (Fig. 11.5D-E), the protocone and the lingual wall of the parastyle, paracone and metastyle are missing. The paracone is the highest cusp of the tooth. The parastyle and metastyle have approximately the same height. The parastyle is shorter than the paracone, while the metastyle is slightly longer than the paracone (Table 11.5). There is a tiny preparastyle at the base of the parastyle mesial wall. A long distal and buccal root lies below the metastyle and most of the paracone. The remaining fragment of a shorter lingual root, beneath the protocone position, indicates that the crown base of the protocone extended mesially to the same level as the parastyle crown base. 
Comparisons. The dimensions and robust morphology of the lower canine and $\mathrm{P} 4$ seem to correspond with the features of AUH 294, the mandible described by Barry (1999) (Table 11.5). Percrocuta sp. from the middle Miocene of Al-Jadidah, Saudi Arabia (listed in Thomas et al. 1978; described and figured in Howell and Petter 1985), represents the only fossil record of Mio-Pliocene hyaenid-like forms in the Arabian Peninsula and nearby regions. Howell and Petter (1985) noted that Percrocuta sp. from Al-Jadidah and P. carnifex from the Indian subcontinent retained a more mesially positioned protocone compared to other percrocutids, as the preserved lingual root portion in AUH 1548 seems to indicate. However, AUH 1548 is longer than the P4 of Percrocuta sp. from Al-Jadidah, and its paracone is longer while its metastyle has approximately the same length (Table 11.5). Werdelin and Solounias (1991) erected the family of hyaenid-like carnivoran Percrocutidae based on the deciduous dentition (dp4) and basicranial characters, but percrocutids also show a reduced protocone on P4, often more distal than the level of the parastyle. This morphological feature, along with the rich fossil record of hyaenids compared to percrocutids during the late Miocene, suggests that the Baynunah form is a large hyaenid. Among the taxa represented in African faunas similar to that of the Baynunah Formation (Bonis et al. 2005, 2007, 2010b for Toros-Menalla [Chad]; Esu and Kotsakis 1980, Howell 1987, Rook and Sardella 2008 for Sahabi [Libya], Werdelin 2003 for Lothagam [Kenya]; Morales et al. 2005 for the Tugen Hills [Kenya]), this hyaenid could correspond in size to Adcrocuta, Werdelinus or Chasmaporthetes. However, more dental material is needed to determine the genus to which it belongs.

\section{Medium-sized HYAENIDAE INDET.}

Previously published material. AUH 370, partial right ulna from Jebel Mimiyah, MIM 1. 
New material. None.

Description. Barry (1999) attributed a single specimen to a hyaenid about the size of a small Crocuta crocuta. No further remains of this taxon have been recovered.

\section{PLACE FIGURE 11.5 ABOUT HERE; WIDTH = 1 COLUMN}

\section{PLACE TABLE 11.5 ABOUT HERE}

\section{Conclusions}

The Carnivora of the Baynunah Formation include a minimum of six species belonging to Mustelidae, Felidae, and Hyaenidae. One machairodontine and one hyaenid are large sizedpredators represented by dental and postcranial elements. Medium-sized taxa are known from dental remains of Plesiogulo sp., forelimb and hindlimb elements of an indeterminate mustelid, $\mathrm{m} 1$ and metacarpals of an indeterminate felid, and an ulna of a second hyaenid species (Barry 1999).

The Baynunah carnivoran assemblage is the richest known from the Miocene of the Arabian Peninsula and nearby regions. Machairodontines reported from the late Miocene Bekaa Valley of Lebanon and possibly from the Jebel Hamrin region of Iraq could be closely related to the Baynunah sabretooth cat. In contrast to the early Miocene Rotem Basin in the Negev and to the middle Miocene Al-Sarrar site in Saudi Arabia, the Baynunah carnivorans do not include any viverrids. Extant viverrids are associated with forested and wooded environments. They are present in many carnivoran faunas from the late Miocene of Eurasia and Africa (e.g., Siwalik Hills, Pikermi, Sahabi, Toros-Menalla, Tugen Hills, Lothagam) and could be expected to be found in the Baynunah fauna at this time as well. However, taxa indicative of wooded habitats, such as monkeys (Gilbert et al. 2014; Gilbert and Hill, this 
volume) or deinotheres (Sanders, this volume), are extremely rare in the Baynunah Formation. Further specimens, especially dental material, will help in refining the taxonomy of these carnivorans, providing essential data for a better understanding of the paleoenvironment of the Arabian Peninsula during the Neogene and the biogeographic relationships between carnivorans of Eurasia (particularly southern Asia) and Afro-Arabia during the late Miocene.

\section{Acknowledgments}

I thank Mark Beech, Brian Kraatz and Faysal Bibi for providing access to the Abu Dhabi material. I thank Morgan Hill from the Microscopy and Imaging Facility (MIF) of the AMNH for taking a SEM photo of the machairodontine upper canine. I also would like to thank Z. Jack Tseng for helpful comments on hyaenid and machairodontine material. I acknowledge Eileen Westwig, Eleanor Hoeger, and Brian O'Toole from the Mammalogy division of the AMNH, and Ruth O'Leary from the Paleontology division of the AMNH for helping with access to extant and extinct species material. I thank Denis Geraads, Lars Werdelin and an anonymous reviewer for their comments contributing to improve this chapter. This research was funded by a US National Science Foundation (NSF) grant (DEB-1257572) and an AMNH Frick Postdoctoral Fellowship to C.H. Fieldwork in the Baynunah Formation was funded by the Abu Dhabi Department of Culture and Tourism (including its previous incarnations) as well as an NSF grant (OISE-0852975) to F. Bibi.

\section{References}


Antón, M., Salesa, M.J., Morales, J., \& Turner, A. (2004). First known complete skulls of the scimitar-toothed cat Machairodus aphanistus (Felidae, Carnivora) from the spanish Late Miocene site of Batallones-1. Journal of Vertebrate Paleontology, 24, 957-969. Barry, J.C. (1999). Late Miocene Carnivora from the Emirate of Abu Dhabi, United Arab Emirates. In P.J. Whybrow \& A.P. Hill (Eds.), Fossil Vertebrates of Arabia: With Emphasis on the Late Miocene Faunas, Geology, and Palaeoenvironments of the Emirate of Abu Dhabi, United Arab Emirates (pp. 203-208). New Haven: Yale University Press.

Bibi, F., Hill, A., Beech, M.J., \& Yasin, W. (2013). Late Miocene Fossils from the Baynunah Formation, United Arab Emirates. In X. Wang, M. Fortelius, \& L.J. Flynn (Eds.), Neogene Terrestrial Mammalian Biostratigraphy and Chronology in Asia (pp 583594). New York: Columbia University Press.

Bibi F., B. Kraatz, M. Beech, and A. Hill. (this volume-a). Sands of Time: Late Miocene Fossils from the Baynunah Formation, U.A.E.. Cham: Springer. xxx pp.

Bibi, F., Beech, M., Hill., A, \& Kraatz, B. (this volume-b). Fossil Localities of the Baynunah Formation. In F. Bibi, B. Kraatz, M. Beech, \& A. Hill (eds.) Sands of Time: Late Miocene Fossils from the Baynunah Formation, U.A.E. (pp. xxx). Cham: Springer.

Bibi, F., Kaya, F., Varela, S. (this volume-c). Paleoecology and Paleobiogeography of the Baynunah Fauna. In F. Bibi, B. Kraatz, M. Beech, \& A. Hill (eds.) Sands of Time: Late Miocene Fossils from the Baynunah Formation, U.A.E. (pp. xxx). Cham: Springer.

Bonis, L. de, Peigné, S., Likius, A., Mackaye H.T., Brunet, M., \& Vignaud, P. (2007). First occurrence of the 'hunting hyaena' Chasmaporthetes in the Late Miocene fossil bearing localities of Toros Menalla, Chad (Africa). Bulletin de la Société Géologique de France, 178, 317-326. 
Bonis, L. de, Peigné, S., Likius, A., Mackaye H.T., Vignaud, P., \& Brunet, M. (2005). Hyaenictitherium minimum, a new ictithere (Mammalia, Carnivora, Hyaenidae) from the Late Miocene of Toros-Menalla, Chad. Comptes Rendus Paleoevol, 4, 671-679.

Bonis, L. de, Peigné, S., Mackaye, H.T., Likius, A., Vignaud P., \& Brunet, M. (2010a). New sabre-tooth cats in the Late Miocene of Toros Menalla (Chad). Comptes Rendus Palevol, 9, 221-227.

Bonis, L. de, Peigné, S., Guy, F., Mackaye H.T., Likius, A., Vignaud, P. et al. (2010b). Hyaenidae (Carnivora) from the Late Miocene of Toros-Menalla, Chad. Journal of African Earth Sciences, 58, 561-579.

Cristiansen, P., \& Adolfssen, J.S. (2007). Osteology and ecology of Megantereon cultridens SE311 (Mammalia; Felidae; Machairodontinae), a sabrecat from the Late Pliocene Early Pleistocene of Senèze, France. Zoological Journal of the Linnean Society, 151, $833-884$.

Crusafont-Pairó, M., \& Aguirre, E. (1971). A new species of Percrocuta from the Middle Miocene of Kenya. Abhandlungen der hessisches Landesamt für Bodenforschung, 60, $5-58$.

Ditchfield, P.W. (1999). Diagenesis of the Baynunah, Shuwaihat, and Upper Dam Formation sediments exposed in the Western Region, Emirate of Abu Dhabi, United Arab Emirates. In P.J. Whybrow \& A. Hill A (Eds.), Fossil Vertebrates of Arabia: With Emphasis on the Late Miocene Faunas, Geology, and Palaeoenvironments of the Emirate of Abu Dhabi, United Arab Emirates (pp. 136-162). New Haven: Yale University Press.

Esu, D., \& Kotsakis, T. (1980). Ictitherium arkesilai sp.n. (Hyaenidae, Carnivora) del Terziario superiore di Sahabi (Cirenaica, Libia). Rivista Italiana di Paleontologia e Stratigrafia, 86, 241-256. 
Gilbert, C.C., Bibi, F., Hill, A., \& Beech, M.J. (2014). Early guenon from the late Miocene Baynunah Formation, Abu Dhabi, with implications for cercopithecoid biogeography and evolution. Proccedings of the National Academy of Sciences, 111, 10119-10124.

Gilbert, C. C., \& Hill, A. (this volume). Primates from the Baynunah Formation. In F. Bibi, B. Kraatz, M. Beech, \& A. Hill (eds.) Sands of Time: Late Miocene Fossils from the Baynunah Formation, U.A.E. (pp. xxx). Cham: Springer.

Haile-Selassie, Y., Hlusko, L.J., \& Howell F.C. (2004). A new species of Plesiogulo (Mustelidae: Carnivora) from the Late Miocene of Africa. Palaeontologica Africana, $40,85-88$.

Hailwood, E.A., \& Whybrow, P.J. (1999). Palaeomagnetic correlation and dating of the Baynunah and Shuwaihat Formations, Emirate of Abu Dhabi, United Arab Emirates. In P.J. Whybrow \& A.P. Hill (Eds.), Fossil Vertebrates of Arabia: With Emphasis on the Late Miocene Faunas, Geology, and Palaeoenvironments of the Emirate of Abu Dhabi, United Arab Emirates (pp. 75-87). New Haven: Yale University Press.

Hamilton, W.R., Whybrow, P.J., \& McClure, H.A. (1978). Fauna of fossil mammals from the Miocene of Saudi Arabia. Nature, 274, 248-249.

Harrison, J.A. (1981). A review of the Extinct Wolverine, Plesiogulo (Carnivora: Mustelidae), from North America. Smithsonian Contributions to Paleobiology, 46, 1-27.

Hearst, J.M., Martin, L.D., Babiarz, J.P., \& Naples, V.L. (2011). Osteology and Myology of Homotherium ischyrus from Idaho. In V.L. Naples, L.D. Martin \& J.P. Babiarz (Eds.), The Other Saber-Tooths: Scimitar-Tooth Cats of the Western Hemisphere (pp. 123184). Baltimore: The John Hopkins University Press.

Hendey, Q.B. (1978). Late Tertiary Mustelidae (Mammalia, Carnivora) from Langebaanweg, South Africa. Annals of the South African Museum, 76, 329-357. 
Howell, F.C. (1987). Preliminary Observations on Carnivora From the Sahabi Formation (Libya). In N.T. Boaz, A. El-Arnauti, A.W. Gaziry, J. de Heinzelin, \& D.D. Boaz (Eds.), Neogene Paleontology and Geology of Sahabi (pp. 154-181). New York: Liss. Howell, F.C., \& Petter, G., (1985). Comparative observations on some Middle and Upper Miocene hyaenids: Genera: Percrocuta Kretzoi, Allohyaena Kretzoi, Adcrocuta Kretzoi (Mammalia, Carnivora, Hyaenidae). Geobios, 18, 419-476.

Kansou, M. (1961). Découverte de vertébrés pontiens au Liban dans la plaine de Békaa. Bulletin Scientifique, Conseil des Academies de la RFP Yougoslavie, Zagreb, 6, 65. Koufos, G.D. (1982). Plesiogulo crassa from the Upper Miocene (Lower Turolian) of Northern Greece. Annales Zoologici Fennici 19, 193-197.

Kurtén, B. (1970). The Neogene wolverine Plesiogulo and the origin of Gulo (Carnivora, Mammalia). Acta Zoologica Fennica, 131, 3-22.

Malez, M., \& Crnolatac, I. (1961). Relations stratigraphiques et paléontologiques du gisement de la faune à Hipparion près de Kefraya (Békaa, Liban). Bulletin Scientifique, Conseil des Academies de la RFP Yougoslavie, Zagreb, 6, 97-98.

Morales, J., Pickford, M., \& Soria, D. (2005). Carnivores from the Late Miocene and Basal Pliocene of the Tugen Hills, Kenya. Revista de la Sociedad Geológica de España, 18, $39-61$.

Nowak, R.M. (1991). Walker's Mammals of the World, fifth edition, Volume II. Baltimore and London: John Hopkins University Press.

Peppe, D. J., Evans, D. A. D., Beech, M., Hill, A., Bibi, F. (this volume). Magnetostratigraphy of the Baynunah Formation. In F. Bibi, B. Kraatz, M. Beech, \& A. Hill (eds.) Sands of Time: Late Miocene Fossils from the Baynunah Formation, U.A.E. (pp. xxx). Cham: Springer. 
Rook, L., \& Sardella, R. (2008). An overview of the As Sahabi carnivore guild with description of new specimens from E.L.N.R.P. field surveys. In N.T. Boaz, A. ElArnauti, P. Pavlakis, \& M. Salem (Eds.), Circum-Mediterranean Geology and Biotic Evolution During the Neogene Period: The Perspective from Libya. Garyounis Scientific Bulletin, Special Issue Number 5 (pp. 257-263). Benghazi: University of Garyounis.

Roussiakis, S.J., Theodorou, G.E., \& Iliopoulos, G. (2006). An almost complete skeleton of Metailurus parvulus (Carnivroa, Felidae) from the late Miocene of Kerassia (Northern Euboea, Greece). Geobios, 39, 563-584.

Salesa, M.J., Antón, M., Turner, A., Alcalá, L., Montoya, P., \& Morales, J. (2010). Systematic revision of the Late Miocene sabre-toothed felid Paramachaerodus in Spain. Palaeontology, 53, 1369-1391.

Sanders, W. J. (this volume). Proboscidea from the Baynunah Formation. In F. Bibi, B. Kraatz, M. Beech, and A. Hill (eds.) Sands of Time: Late Miocene Fossils from the Baynunah Formation, U.A.E. (pp. Xxx). Cham: Springer

Schlosser, M. (1903). Die fossilien Säugethiere Chinas nebst einer Odontographie der recenten Antilopen. Abhandlungen der Bayerischen Akademie der Wissenschaften, 22, 1-22.

Schuster, M. (this volume). Sedimentology and Stratigraphy of the Baynunah Formation. In F. Bibi, B. Kraatz, M. Beech, and A. Hill (eds.) Sands of Time: Late Miocene Fossils from the Baynunah Formation, U.A.E. (pp. xxx). Cham: Springer.

Tchernov, E., Ginsburg, L., Tassy, P., \& Goldsmith, N.F. (1987). Miocene mammals of the Negev (Israel). Journal of Vertebrate Paleontology, 7, 284-310.

Teilhard de Chardin, P. (1945). Les formes fossiles. In P. Teilhard de Chardin \& P. Leroy, Les Mustelidés de Chine (pp. 3-36). Pekin (Beijing): Publications de l'Institut de Geobiologie No 12. 
Thomas, H., Sen, S., \& Ligabue, G. (1980). La faune miocène de la formation Agha Jari du Jebel Hamrin (Irak). Proceedings of the Koninklijke Nederlandse Akademie van Wetenschappen B, 83, 269-287.

Thomas, H., Taquet, P., Ligabue, G., \& Del'Agnola, C. (1978). Découverte d'un gisement de Vertébrés dans les dépôts continentaux du Miocène moyen du Hasa (Arabie Saoudite). Compte Rendu Sommaire des séances de la Société Géologique de France, 2, 69-72.

Thomas, H., Sen, S., Khan, M., Battail, B., \& Ligabue, G. (1982). The lower Miocene fauna of Al-Sarrar (Eastern province, Saudi Arabia). ATLAL, The Journal of Saudi Arabian Archaeology, 5, 109-136.

Thomas, H., Roger, J., Sen, S., Pickford, M., Gheerbrant, E., Al-Sulaimani, Z., et al. (1999). Oligocene-Miocene terrestrial vertebrates in the southern Arabian peninsula (Sultanate of Oman) and their geodynamic and palaeogeographic settings. In P. J. Whybrow \& A. Hill (Eds), Fossil Vertebrates of Arabia (pp. 430-442). New Haven: Yale University Press.

Whybrow, P.J., \& Clements, D. (1999) Late Miocene Baynunah Formation, Emirate of Abu Dhabi, United Arab Emirates: Fauna, flora, and localities. In P.J. Whybrow \& A.P. Hill (Eds.), Fossil Vertebrates of Arabia, with Emphasis on the Late Miocene Faunas, Geology, and Palaeoenvironments of the Emirate of Abu Dhabi, United Arab Emirates (p 317-333). New Haven: Yale University Press.

Werdelin, L. (2003). Mio-Pliocene Carnivora from Lothagam, Kenya. In M.G. Leakey \& J.D. Harris (Eds.), Lothagam: The dawn of humanity in eastern Africa (pp. 261-328). New York: Columbia University Press.

Werdelin, L., \& Lewis, M.E. (2001). A revision of the genus Dinofelis (Mammalia, Felidae). Zoological Journal of the Linnean Society, 132, 147-258. 
Werdelin, L., \& Solounias, N. (1991). The Hyaenidae: taxonomy, systematics and evolution. Fossil and Strata, 30, 1-104.

Werdelin, L., Yamaguchi, N., Johnson, W.E., \& O’Brien, S.J. (2010). Phylogeny and evolution of cats (Felidae). In D.M. Macdonald \& A. Loveridge (Eds.), The Biology and Conservation of Wild Felids (pp. 59-82). Oxford: Oxford University Press.

Zdansky, O. (1924). Jungertertiare Carnivoren Chinas. Palaeontologica Sinica C, 2, 1-155. 


\section{Figure captions}

Figure 11.1. A, Locations of Miocene Carnivora-bearing localities of the Arabian Peninsula: Early Miocene Hatzeva Formation, Negev; early Miocene Dam Formation, Ghaba, Sultanate of Oman; late early Miocene Dam Formation, Al-Sarrar (=As-Sarrar), Saudi Arabia; middle Miocene Hofuf Formation, Al-Jadidah, Saudi Arabia; middle Miocene Dam Formation, AdDabtiyah, Saudi Arabia; late Miocene Lower Bakhtiari Formation, Jebel Hamrin, Iraq; late Miocene Bekaa Valley, Lebanon; late Miocene Baynunah Formation, Abu Dhabi, UAE. B, Carnivora-bearing sites in the Baynunah Formation: GAA, Gerain al-Aysh; HAD, Hadwaniya; HMR, Hamra; JDH, Jebel Dhanna; KIH, Kihal; MIM, Jebel Mimiyah; RDB, Ras Dubay’ah; RUW SE, Ruwais South East; SHU, Shuwaihat; THM, Thumayriya. Satellite image from Google Earth.

Figure 11.2. Mustelidae indet.: right humerus AUH 1752 in anterior (A), lateral (B), posterior (C) and medial (D) views; left ulna AUH 1055 in anterior (E), lateral (F), and medial (G) views; right distal femur AUH 1046 in anterior $(\mathrm{H})$, posterior $(\mathrm{I})$ and lateral $(\mathrm{J})$ views. Scale $=$ $20 \mathrm{~mm}$ from A-J. Plesiogulo sp.: left M1 AUH 1762 in occlusal view (K). Scale $=10 \mathrm{~mm}$ for $\mathrm{K}$.

Figure 11.3. Homotherini indet.: upper canine AUH 1756 in lateral view, scale $=10 \mathrm{~mm}$ (A), coarse crenulations of an enamel fragment AUH 1756 observed with SEM, scale = $2 \mathrm{~mm}(\mathrm{~B})$; distal right humerus AUH 1056 in anterior (C) and posterior (D) views; right calcaneum AUH 241 in dorsal (E), medial (F), ventral $(\mathrm{G})$ and lateral $(\mathrm{H})$ views; distal metapodial bone AUH 852 in dorsal (I) and ventral (J) views; cast of the lumbar vertebra AUH 1576 in dorsal (K), anterior (L), right lateral (M), posterior $(\mathrm{N})$ views; last lumbar vertebra AUH 202 in dorsal 
$(\mathrm{O})$, anterior $(\mathrm{P})$, right lateral $(\mathrm{Q})$, posterior $(\mathrm{R})$ views; cast of the caudal vertebra AUH 1678 in right lateral view (S). Scale $=20 \mathrm{~mm}$ for C-D and for E-S.

Figure 11.4. Felidae indet.: partial left $\mathrm{m} 1$ AUH 858 in buccal (A) and lingual (B) views; cast of the right metacarpal V AUH 1202 in proximal (C), dorsal (D), medial (E), ventral (F), lateral (G) views; cast of left metacarpal V AUH 1292 in proximal (H), dorsal (I), and lateral (J) views. Scale $=10 \mathrm{~mm}$ for A-B and for C-J.

Figure 11.5. Hyaenidae indet.: right lower canine AUH 1788 in lingual (A), distal (B), and labial (C) views; cast of the right P4 AUH 1548 in labial (D) and occlusal (E) views. Scale = $10 \mathrm{~mm}$.

Table 11.1. Measurements (in $\mathrm{mm}$ ) of lower and upper teeth of Plesiogulo sp. from Abu Dhabi. Measurements in parentheses for the buccal side of the tooth; Asterisk indicates an 
approximate measurement due to a broken part; Personal measurements and from ${ }^{1}$ Barry (1999).

$\begin{array}{lllll}\mathrm{p} 2 & \mathrm{p} 3 & \mathrm{p} 4 & \mathrm{~m} 1 & \mathrm{M} 1\end{array}$

Plesiogulo sp.

AUH 45 (left mandible) ${ }^{1}$

$7 \times 4.7 \quad 8.3 \times 5.4 \quad 10.9 \times 6.1 \quad 21.2 \times 8.1$

AUH 702 (right mandible) ${ }^{1}$

$9.2 \times 6$

AUH 1762 (left M1)

$11.48\left(8^{*}\right) \times 13.84$ 
Table 11.2. Measurements (in $\mathrm{mm}$ ) of postcranial specimens of Mustelidae indet.

Measurements for the ulna and femur are estimated based on photos.

maximum proximodistal length of the proximal

$\begin{array}{lrr}\text { AUH } 1752 \text { (right humerus) } & \text { fragment } & 30.72\end{array}$

maximum proximodistal length of the distal fragment $\quad 81.38$

mediolateral width of the humeral head $\quad 25.58$

anteroposterior width of the humeral head $\quad 24.78$

mediolateral width of the distal epiphysis $\quad 31.3$

anteroposterior width of the distal epiphysis $\quad 15.46$

AUH 1055 (left ulna) $\quad$ maximum proximodistal length $\quad 84.2$

height of the trochlear notch laterally $\quad 16.84$

height of the trochlear notch medially $\quad 12.63$

maximum height of the radial notch $\quad 8.16$

maximum mediolateral width of the radial notch $\quad 8.8$

$\begin{array}{ll}\text { anteroposterior width at the midshaft } & 10.27\end{array}$

$\begin{array}{ll}\text { mediolateral width at the midshaft } & 7.37\end{array}$ 
Table 11.3. Measurements (in $\mathrm{mm}$ ) of the upper canine and postcranial specimens of Homotherini indet. Measurements for the humerus and metapodial are estimated based on photos. Asterisk indicates an approximate measurement due to a broken part and measurements of length and width not taken from the junction enamel-dentine, as absent in the specimen. 
Table 11.4. Measurements (in $\mathrm{mm}$ ) of the postcranial specimens of medium-sized Felidae indet. 
Table 11.5. Dental measurements (in $\mathrm{mm}$ ) of the large-sized Hyaenidae indet. from Abu Dhabi and Percrocuta sp. from Al-Jadidah, late Miocene of Saudi Arabia. Personal measurements and from ${ }^{1}$ Barry (1999), ${ }^{2}$ Howell and Petter (1985). L=length.

\begin{tabular}{lccccc}
\hline Hyaenidae indet. & c & dp2 & P4 & LparaconeP4 & LmetastyleP4 \\
AUH 1788 (right canine) & $16.84 \times 13.54$ & & & & \\
& & & & & \\
AUH 294 (left mandible) & & & & & \\
& & $16.2 \times 9$ & & & \\
AUH 1548 (right P4) & & & $33.52 \times ?$ & 11.6 & 12.18
\end{tabular}

Percrocuta sp. from Al-Jadidah

MNHN unnumbered (right

maxilla $)^{2}$ 
Fig 11.1

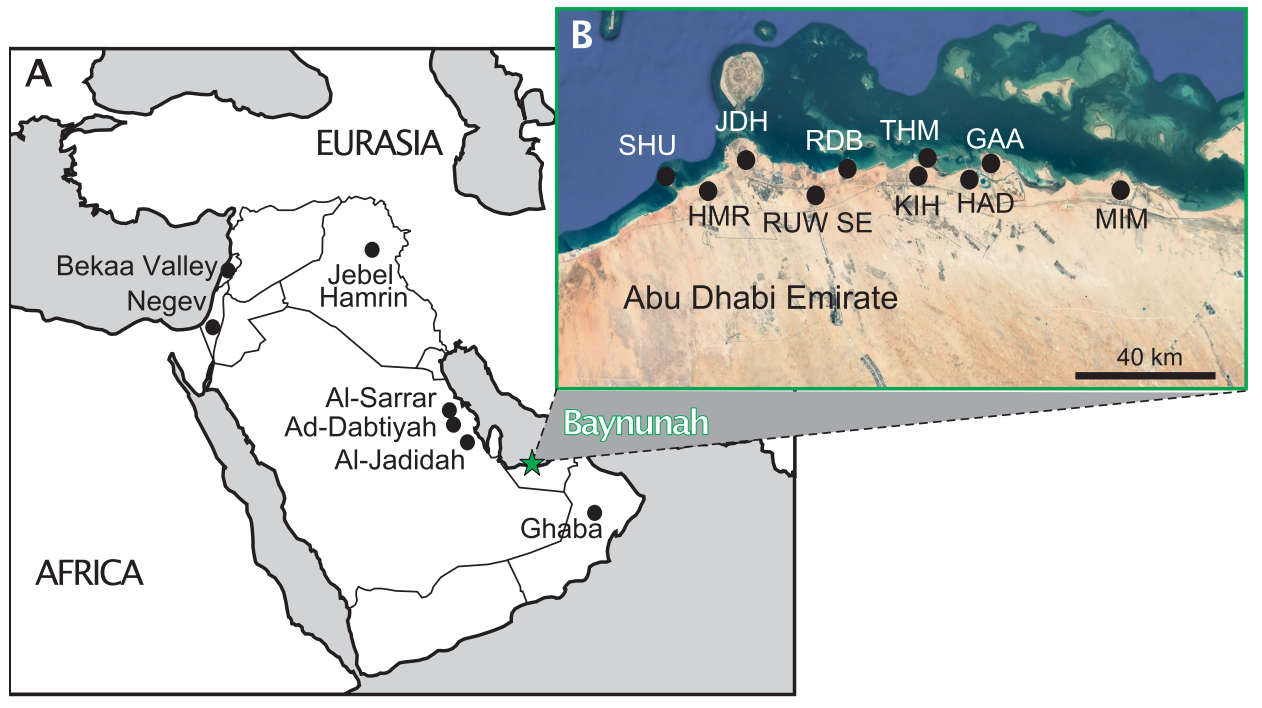


Fig 11.2

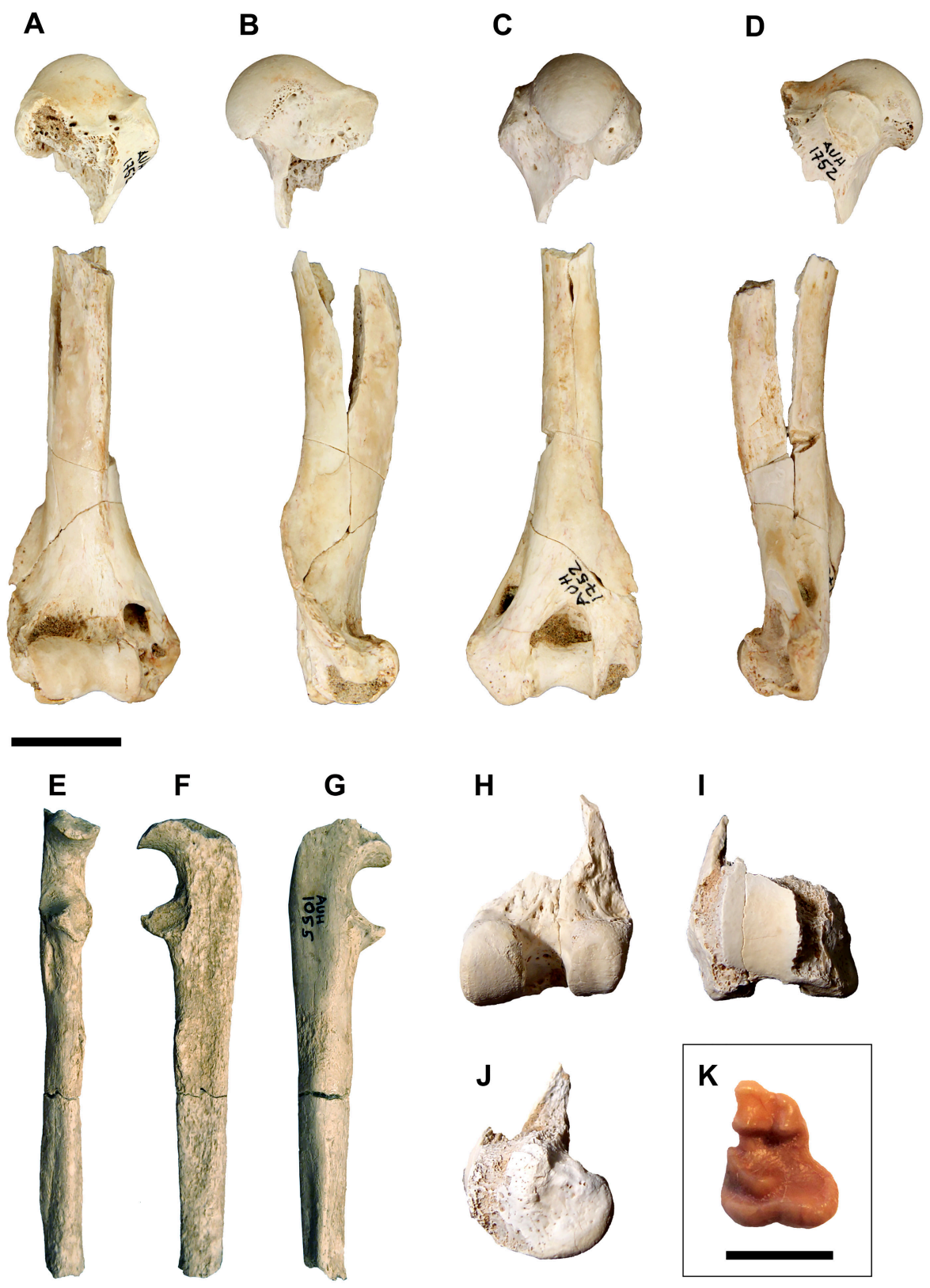


Fig 11.3
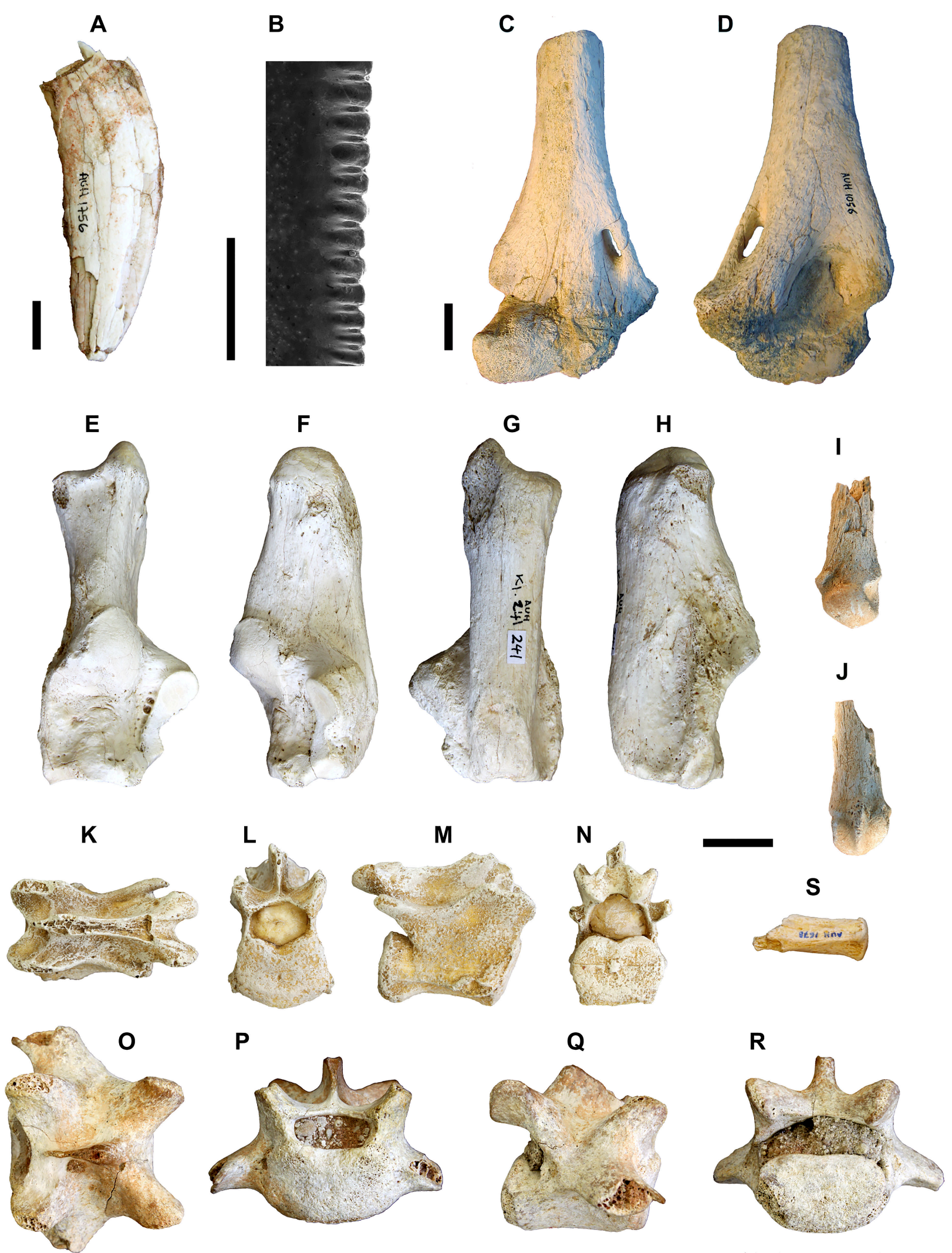
Fig 11.4

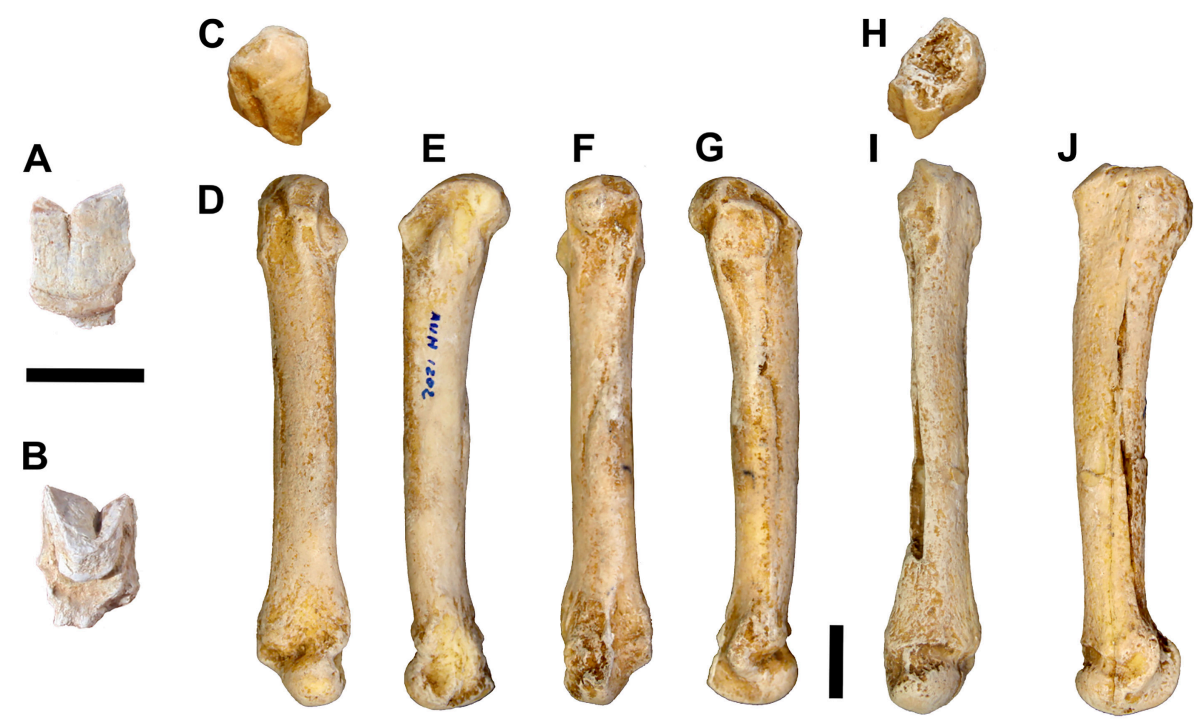


Fig 11.5

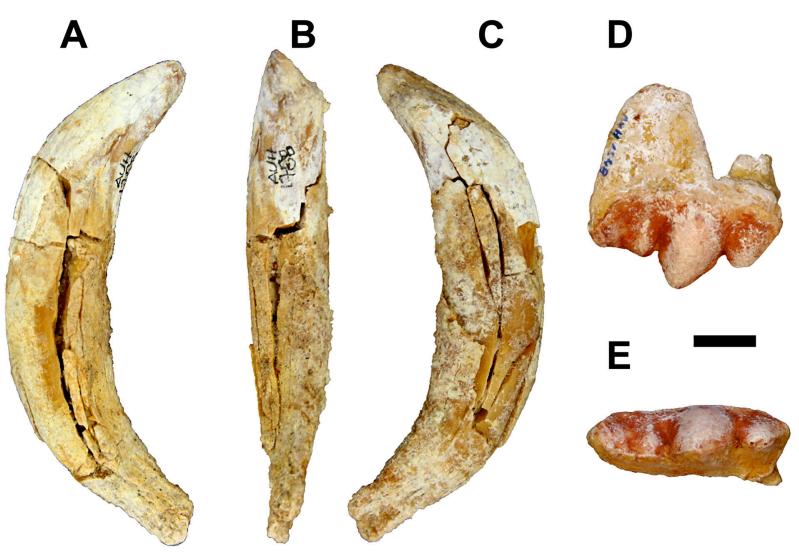

